Creative Commons User Licence: CC BY-NC-ND

Abstracted by: EBSCOhost, Electronic Journals Service (EJS),

Google Scholar, Directory of Open Access Journals (DOAJ),

Journal Seek, Scientific Commons, and

Food and Agricultural Organization (FAO)
Journal of Agricultural Extension

Vol.19 (1) June, 2015

ISSN 24086851

http://journal.aesonnigeria.org

http://www.ajol.info/index.php/jae

http://dx.doi.org/10.4314.jae.v19i1.2

\title{
Determinants of Use of Indigenous Fish Processing Practices in Maritime and Inland States of Nigeria
}

\section{Mercy Opeoluwa Adeogun', Oludare Akanni Adeogun²}

${ }^{1}$ Federal College of Fisheries and Marine Technology, Victoria Island Lagos, Nigeria

${ }^{2}$ Nigeria Institute of Oceanography and Marine Research, 3, Wilmot Point Rd., Victoria Island Lagos

\section{Abstract}

The study examined the various factors affecting the level of utilization of Indigenous Fish Processing Practices \{IFPP\} in Maritime and Inland States of Nigeria. The study was carried out in four fish processing states viz; Akwa -Ibom and Lagos (Maritime states) while Borno and Niger(Inland states). From snowball generated lists, 74, 34, 34 and 47 respondents were randomly selected from the states, respectively. Primary data were collected through the use of interview schedule. Descriptive statistics was used to analyze the socio-economic features of the fish processors while the logit model was used to capture the socio-economic factors determining the utilization of indigenous fish processing practices. The result of the logit model shows that in maritime states, age $(\beta=0.01)$, sex $(\beta=3.46)$, education $(\beta=1.90)$, household size $(\beta=2.48), F A I(\beta=2.80)$, consumers preference $(\beta=3.37)$, processing tradition $(\beta=3.74), \operatorname{VFP}(\beta=0.02)$ and cosmopoliteness $(\beta=4.11)$ were prominent factors likely to determine IFPPs use significantly. In Inland states, age $(\beta=0.05)$, sex $(\beta=3.45)$, consumer preference $(\beta=2.90)$, income generating activities at peak season $(\beta=2.26), \operatorname{VFP}(\beta=2.39)$ and cosmopoliteness $(\beta=0.41)$ were significant factors likely determining IFPP use. Factors influencing use of indigenous fish processing practices were similar in maritime and inland states. However, income generating activity was a peculiar factor influencing indigenous fish processing practices in inland states, while processing tradition, education and household size were peculiar factors in maritime states.

Therefore, development program should consider the aforementioned factors while adequate consideration should be on IFPPs as a spring board to development of affordable, accessible and sustainable intervention.

\section{Key words: Indigenous Fish Processing Practices, Maritime, Inland}


Creative Commons User Licence: CC BY-NC-ND

Abstracted by: EBSCOhost, Electronic Journals Service (EJS),

Google Scholar, Directory of Open Access Journals (DOAJ),

Journal Seek, Scientific Commons, and

Food and Agricultural Organization (FAO)
Journal of Agricultural Extension

Vol.19 (1) June, 2015

ISSN 24086851

http://journal.aesonnigeria.org

http://www.ajol.info/index.php/jae

\section{Introduction}

The call and encouragement for improvement of fish production and value chain in Nigeria can only be achieved through effective extension effort and services and fisher folks knowledge for sustainable fisheries development. This relationship existed but little effect has the introduction of improved technology brought to reduce post harvest loss and increased availability of fish that met consumer's preferences. The fishers still rely on their indigenous practices for development and ignored the improved technologies introduced ( Adeogun 2011).

It may be erroneous to assume that the improved processing technology is adopted/adapted and performing well to improve value addition and reduce loss. In a bid to reduce malnutrition and accomplish self-sufficiency in fish production, knowledge and technological development of means of fish production, processing, storage and marketing was introduced to the fishing communities. However, these interventions failed to achieve the desired result of overcoming the perishability of fish, enhanced nutritional value and adding economic value through processing as the main ways of improving food security in Nigeria.

The low use of such fisheries knowledge and technology of fish processing and upon the widening perishability of fish has created a gap in meeting the fish self sufficiency to reduce malnutrition and sustainable fisheries development. However, the challenges Nigeria fisheries are facing are more daunting in that research and extension system, as they are practised today, are not geared to meet the challenges. New challenges are fishers' knowledge systems as the starting point to enhance their self-esteem blending indigenous and modern technologies to enhances the ecological sustainability, better-quality products and new products, reduce loss of bio- diversity, climate change, environmental degradation, etc and also, persistence of poverty and future food security.

Furthermore, Indigenous Knowledge is used at the local level by communities as the basis for decisions pertaining to food security, human and animal health, education, natural resources management, and other vital economic and social activities (Gorjestani, 2000).

The utilization of indigenous knowledge is of utmost importance in the fishery industry, especially with regard to the prevailing problem of post-harvest losses, which according to Bolorunduro (1996) may affect about $50 \%$ of estimated daily harvests.

More so, the Fishers have their practices in fishing and post harvest handlings that have been acquired either through culture by adjusting to circumstances and their environment which has benefited them immensely. If a project now overlooks these traditions and introduces new fish processing practices/methods, particularly those which require inputs from resources outside the community, the heritage of fishing and fish processing may be lost, local people may not be 
Creative Commons User Licence: CC BY-NC-ND

Abstracted by: EBSCOhost, Electronic Journals Service (EJS),

Google Scholar, Directory of Open Access Journals (DOAJ),

Journal Seek, Scientific Commons, and

Food and Agricultural Organization (FAO)
Journal of Agricultural Extension

Vol.19 (1) June, 2015

ISSN 24086851

http://journal.aesonnigeria.org

http://www.ajol.info/index.php/jae

interested in project activities and therefore, the long-term sustainability of project outcomes may be low.

Utilizing Indigenous Knowledge helps to increase the sustainability of development efforts because the Indigenous Knowledge integration process provides for mutual learning and adaptation, which in turn contributes to the empowerment of local communities, since efficiency, effectiveness, and sustainability are key determinants of the quality of development work.

However, many organizations recognize and are working to document and support the development of farmers and fishers innovations. This goes a step further than just encouraging participation in research but encouraging farmers' own experimentation as a valid starting point. There is therefore the need to document the determinants of Indigenous Fish Processing Practices utilization in the maritime and inland states of Nigeria.

An understanding of the determinants of utilization of Indigenous fish processing Practices (IFPP) should provide platform upon which effective and sustainable fish processing technology could be laid.

The general objective was to document the determinants of Indigenous Fish Processing Practices utilization in the maritime and inland states of Nigeria;

The specific objectives were to:

1. describe fish processors' selected personal characteristics;

2. Identify sources of information of the indigenous practices

3. investigate the fish processors' constraints in fish processing using indigenous knowledge practices;

\section{Methodology}

The study population consisted of both male and female fish processors in the Maritime and Inland States of Nigeria. A multi-stage random sampling technique was used to select the respondents. Fish producing states in Nigeria was stratification into Maritime and Inland States, two states were purposively selected from each stratum viz; Lagos, Akwa-Ibom states from Maritime and Borno, Niger states from Inland. Then cluster sampling technique was used for the selection of Local Government Areas (LGAs) and processing centers. 
Creative Commons User Licence: CC BY-NC-ND

Abstracted by: EBSCOhost, Electronic Journals Service (EJS),

Google Scholar, Directory of Open Access Journals (DOAJ),

Journal Seek, Scientific Commons, and

Food and Agricultural Organization (FAO)
Journal of Agricultural Extension

Vol.19 (1) June, 2015

ISSN 24086851

http://journal.aesonnigeria.org

http://www.ajol.info/index.php/jae

From the processing centers, list of processors was complied through snowball and a sampling frame of 189 respondents were randomly selected.

Primary data were collected through the use of validated interview schedule and in-depthinterview (IDI) sessions on the objectives of the study. Descriptive statistics was used to analyze the socio- economic features of the fish processors while the logit model was used to capture the socio-economic factors determining the utilization of indigenous fish processing practices.

\section{Results and Discussion}

\section{Personal Characteristics of Respondents}

The findings in Table 1 revealed that majority $(66.6 \%)$ of the respondents had household size between 1- 4. Also, 30.1\% of the respondents had 6-10 years of experience which is borne out of continuous experimentation, innovation and adaptation and blending many knowledge systems to solve problems on fish processing.

Table 1 also revealed that the major sources of information to fish processors in the study area were elders and friends. Friends accounted for 32.8\% and elders 67.2\%. This is contrary to Davies and Davies (2009) findings of fellow fish processors as a major source of information available to the fish processors. The implication for extension is that friends and elders should be looked into as agents for disseminating information on sustainable technology in fish processing.

\section{Constraints Identified in the Use of Indigenous Fish Processing Practices (IFPPs)}

Table 2 showed that majority, $96.8 \%$ of the respondents in all the locations indicated that low batch of processing equipment was the major constraint faced by processor. Other constraints include health challenges in which about $75.0 \%$ of the fish processors attested to. Also identified as part of the constraint was high fuel consumption, $70.9 \%$, while $48.2 \%$ of the respondents see fish processing as cumbersome practices. 
Creative Commons User Licence: CC BY-NC-ND

Abstracted by: EBSCOhost, Electronic Journals Service (EJS),

Google Scholar, Directory of Open Access Journals (DOAJ),

Journal Seek, Scientific Commons, and

Food and Agricultural Organization (FAO)
Journal of Agricultural Extension

Vol.19 (1) June, 2015

ISSN 24086851

http://journal.aesonnigeria.org

http://www.ajol.info/index.php/jae

Table 1: Percentage distribution of respondents according to selected personal characteristics

\begin{tabular}{lccc}
\hline Variables & & Percentages & \\
& & & \\
& & & \\
Household size & Marine & Inland & Total \\
& & & \\
$1-4$ & 70.3 & 44.4 & 66.6 \\
$5-8$ & 22.2 & 17.6 & 23.1 \\
$9-12$ & 7.4 & 7.4 & 8.6 \\
$13-16$ & 0.0 & 3.7 & 2.2 \\
$>17$ & 0.0 & 9.3 & 5.4 \\
Experience in fish processing (Years) & & & \\
$1-5$ & 68.5 & 7.7 & 21.5 \\
$6-10$ & 28.7 & 32.1 & 30.1 \\
$11-15$ & 2.8 & 6.4 & 4.3 \\
$16-20$ & 0.0 & 7.7 & 3.2 \\
$21-25$ & 0.0 & 44.9 & 18.8 \\
$>26$ & 0.0 & 1.3 & 0.5 \\
Information source on fish processing & & & \\
Elders & 53.7 & 85.9 & 67.2 \\
Friends & 46.3 & 14.1 & 32.8 \\
Extension agents & 0.0 & 0.0 & 0.0 \\
Television & 0.0 & 0.0 & 0.0 \\
Radio & 0.0 & 0.0 & 0.0
\end{tabular}


Creative Commons User Licence: CC BY-NC-ND

Abstracted by: EBSCOhost, Electronic Journals Service (EJS),

Google Scholar, Directory of Open Access Journals (DOAJ),

Journal Seek, Scientific Commons, and

Food and Agricultural Organization (FAO)
Journal of Agricultural Extension

Vol.19 (1) June, 2015

ISSN 24086851

http://journal.aesonnigeria.org

http://www.ajol.info/index.php/iae

Table 2: Constraints identified in the use of Indigenous Fish Processing Practices

\begin{tabular}{lc}
\hline Problems identified in the use of IKPs & Percentages \\
\hline Long processing time & 30.2 \\
*High fuel consumption & 70.9 \\
*Cumbersome practice & 48.2 \\
High initial capital & 16.6 \\
Poor quality product & 9.5 \\
*Low batch & 96.8 \\
*Discomfort/Smoke entering eyes & 74.6 \\
Practice is cumbersome & 40.2 \\
\end{tabular}

\section{*Multiple Responses}

\section{Factors determining use of IFPPs}

Several factors were responsible for using the IFPPs respondents. Some of the factors obtained during Indepth interview and Focus Group Discussions (FGDs) includes; compatible equipment; profitability; peoples' culture. Other were ease of use and teaching new generation, low cost, improve value, gives longer shelve life; IFPPs features; such as users friendly, better results, cheap, fuel efficiency, materials sourced locally, openness, simple and communicability. 
Creative Commons User Licence: CC BY-NC-ND

Abstracted by: EBSCOhost, Electronic Journals Service (EJS),

Google Scholar, Directory of Open Access Journals (DOAJ),

Journal Seek, Scientific Commons, and

Food and Agricultural Organization (FAO)
Journal of Agricultural Extension

Vol.19 (1) June, 2015

ISSN 24086851

http://journal.aesonnigeria.org

http://www.ajol.info/index.php/jae

\section{Contribution of Personal/Socioeconomic Characteristics of respondents to Use of IFPPs}

The result of the logit regression on the socio economic characteristics of the fish processors and use of IFPP is shown in Table 2. In Inland area, all the explanatory variables such as age, sex, marital status, frequency of information, consumer preference, income generating activities, experience in fish processing, volume of fish processed and number of time visiting town have the expected signs. With the exception of education, household size, days for processing, and custom of processing fish, the estimated coefficients for parameters like, age $(t=2.103 ; \beta=0.047)$, sex $(t=4.162 ; \beta=3.448)$, consumer preference $(t=3.574 ; \beta=2.898)$, income generating activities at

peak season $(\mathrm{t}=11.582 ; \beta=2.256)$, volume of fish processed $(\mathrm{t}=13.0085 ; \beta=2.385)$ and cosmopoliteness ( $\mathrm{t}=2.361 ; \beta=0.412)$ were significant at $5 \%$ level. The findings of this study agrees with Kolawole (2001), where age, family size, religion, education, farm size, association membership, farming scope, and income level were significant factors to the use of Indigenous knowledge systems for soil fertility conservation. This implies that there was significant relationship between the parameters above and indigenous fish processing practices use. These parameters contribute to the use of indigenous knowledge practices. That is, older processors may not use tedious practices because of weakness. Education also affects the use of IFPP since the well educated is expected not to use IFPP. The significance of these variables indicates that these factors are required for consideration in the formulation of IFPPs use strategies in the study area.

In the same way, marital status, education, numbers of days for processing fish, frequency of information, customs of processing fish, experience in processing, and household size were not significant and does not have relationship with the use of indigenous knowledge practices. However, in Maritime States, variables such as size of household, days for processing, income generated at peak, volume of fish processed and number of time visiting town have the expected signs while others such as age, sex, marital status, frequency of information, consumer preference, custom of processing and experience in fish processing differs from the a priori expectation. Also, in Maritime States significant variables to the use of indigenous practices includes, age $(\mathrm{t}=-4.539$; $\beta=0.012)$, sex $(t=-5.979 ; \beta=3.455)$, education $(t=-3.219 ; \beta=1.904)$, household size $(t=4.000$; $\beta=2.478)$, frequency of accessing information $(t=-3.925 ; \beta=2.801)$, consumers preference $(t=-$ $6.099 ; \beta=3.367)$, processing tradition $(t=-4.879 ; \beta=3.739)$, Volume of fish processed $(t=2.463$; $\beta=0.02)$ and cosmopoliteness $(t=4.767 ; \beta=4.109)$. This implies that the higher the variable, the more likely the fish processors will use any of the indigenous knowledge practices. For instance, with respect to age, the higher the age of the processors, the more likely the fish processors will use one form of indigenous knowledge or the other. In terms of signs and magnitude, the age of the processors was consistent with the a priori expectation in the maritime states. 
Creative Commons User Licence: CC BY-NC-ND

Abstracted by: EBSCOhost, Electronic Journals Service (EJS),

Google Scholar, Directory of Open Access Journals (DOAJ),

Journal Seek, Scientific Commons, and

Food and Agricultural Organization (FAO)
Journal of Agricultural Extension

Vol.19 (1) June, 2015

ISSN 24086851

http://journal.aesonnigeria.org http://www.ajol.info/index.php/iae

The age of the processors was found to be negative but statistically significant at $5 \%$ level. This implies that younger fish processors are more likely to use the indigenous knowledge practices than the older ones. In the Inland States, the age of processors was positive and significant. Consumer's preference was found to be positive and statistically significant in the inland states but negative and significant in the maritime states. It means that consumer's preference will make fish processors use more of the indigenous knowledge so as to meet the demand of the consumers.

This is an indication that these variables have relationship with the Indigenous Practices (IP) use in fish processing. The implication of this finding for extension is that since younger educated processors are exposed to different IFPPs they tend to use more indigenous practices in order to maximise the benefits of use on their processing business. The younger processors should be the primary target of extension information regarding modification on Indigenous Fish Processing Practices. This is in line with the findings of Akinola, (1987) Voh, (1982) Polson and Spencer, (1992) that younger farmers have greater flexibility in accepting new ideas.

The summary of the findings shows that we reject the null hypothesis which states that there is no significant relationship in the selected personal and socioeconomic characteristics and the indigenous knowledge practices use. And we accept the alternative hypothesis. 
Creative Commons User Licence: CC BY-NC-ND

Abstracted by: EBSCOhost, Electronic Journals Service (EJS),

Google Scholar, Directory of Open Access Journals (DOAJ),

Journal Seek, Scientific Commons, and

Food and Agricultural Organization (FAO)
Journal of Agricultural Extension

Vol.19 (1) June, 2015

ISSN 24086851

http://journal.aesonnigeria.org

http://www.ajol.info/index.php/iae

Table 2: Logit Model Analysis of selected personal characteristics of respondent and use of IFPPs

\begin{tabular}{|c|c|c|c|c|}
\hline \multirow[t]{2}{*}{ Parameter } & \multicolumn{2}{|c|}{ Inland } & \multicolumn{2}{|c|}{ Marine } \\
\hline & $\begin{array}{l}\text { Regression } \\
\text { coefficient }\end{array}$ & $\mathbf{T}$ & $\begin{array}{l}\text { Regression } \\
\text { coefficient }\end{array}$ & $\mathbf{T}$ \\
\hline Intercept & -2.756 & & 1.857 & \\
\hline Age & $0.047(0.022)$ & $2.1035^{*}$ & $-0.012(0.03)$ & $-4.538 *$ \\
\hline Sex & $3.448(0.837)$ & $4.1625^{*}$ & $-3.455(0.578)$ & $-5.979 *$ \\
\hline Marital status & $0.470(0.326)$ & 1.44 & $-0.628(0.831)$ & -0.755 \\
\hline Educations & $-0.856(0.563)$ & -1.519 & $-1.904(0.591)$ & $-3.219^{*}$ \\
\hline Size of household & $-0.003(0.035)$ & -0.108 & $2.478(0.616)$ & $4.025^{*}$ \\
\hline Frequency of information & $0.120(0.337)$ & 0.356 & $-2.801(0.714)$ & $-3.925^{*}$ \\
\hline Days for processing & $-0.579(1.009)$ & -0.574 & $1.731(0.930)$ & 1.862 \\
\hline Consumer preference & $2.898(0.811)$ & $3.5745^{*}$ & $-3.367(0.552)$ & $-6.099 *$ \\
\hline $\begin{array}{l}\text { Custom/tradition of } \\
\text { processing }\end{array}$ & $-0.122(0.567)$ & 0.216 & $-3.739(0.766)$ & $-4.879 *$ \\
\hline Income generated at peak & $2.256(0.195)$ & $11.582 *$ & $0.364(0.447)$ & 0.815 \\
\hline $\begin{array}{l}\text { Experience in fish } \\
\text { processing }\end{array}$ & $0.048(0.026)$ & 1.843 & $-0.531 \quad(0.402)$ & -1.32 \\
\hline Volume of fish processed & $2.385(0.183)$ & $13.0085^{*}$ & $0.02(0.001)$ & $2.463 *$ \\
\hline Cosmopoliteness & $0.412(0.174)$ & $2.3615^{*}$ & $4.109(0.862)$ & $4.767 *$ \\
\hline Chi-square & 58.762 & $\mathrm{p}<0.0001$ & 60.612 & $\mathrm{p}<0.0001$ \\
\hline
\end{tabular}

Figure in parenthesis are standard errors of regression coefficient 
Creative Commons User Licence: CC BY-NC-ND

Abstracted by: EBSCOhost, Electronic Journals Service (EJS),

Google Scholar, Directory of Open Access Journals (DOAJ),

Journal Seek, Scientific Commons, and

Food and Agricultural Organization (FAO)
Journal of Agricultural Extension

Vol.19 (1) June, 2015

ISSN 24086851

http://journal.aesonnigeria.org

http://www.ajol.info/index.php/jae

\section{Conclusion and Recommendations}

It is obvious that the Unified Agricultural Extension Service (UAES) must revamp and capacitate its fishery extension unit, it should also recognizance the effect of fishers and fish processors knowledge as essential in the information, selection and adaptation process of technologies. Friends and elders should also be looked into as agents for disseminating information on sustainable technology in fish processing.

Factors such as compatible equipment; profitability; peoples' culture must be considered by extension service as factors determining use of IFPPs. Also, the result of the logit model shows that in maritime states, age, sex, education, household consumers' preference, size, processing tradition, and cosmopoliteness were prominent factors likely to determine IFPPs utilization. In the Inland states, age, sex, consumer preference, income generating activities at peak season, Volume of Fish Processed and cosmopoliteness were significant factors likely determining IFPP utilization. Factors influencing utilization of indigenous fish processing practices were similar in maritime and inland states. However, income generating activity was a peculiar factor determining indigenous fish processing practices in inland states, while processing tradition, education and household size were peculiar factors in maritime states.

Therefore, development program should consider the aforementioned factors while adequate consideration on IFPPs as a spring board to development of affordable, accessible and sustainable intervention that reduce post harvest losses, to ensure sustainable development.

\section{References}

Adeogun,M. O. 2011. Factors influencing the use of indigenous knowledge practices in fish processing in Nigeria Ph.D Thesis. Department of Agricultural Extension and Rural Develoment. Ibadan. University of Ibadan.Nigeria

Akinola, A.A., 1987. An application of the Probit analysis to the adoption of the tractor hiring service scheme in Nigeria. Oxford Agrarian Studies, 16: 70-82.

Bolorunduro, P.I., 1996. "Livestock and fisheries production technology for Women in Agriculture". In: Proceedings of the National Training Workshop of the National Agricultural Extension Research Liaison Services (NAERLS), p: 9. Samaru, Zaria 
Creative Commons User Licence: CC BY-NC-ND

Abstracted by: EBSCOhost, Electronic Journals Service (EJS),

Google Scholar, Directory of Open Access Journals (DOAJ),

Journal Seek, Scientific Commons, and

Food and Agricultural Organization (FAO)
Journal of Agricultural Extension

Vol.19 (1) June, 2015

ISSN 24086851

http://journal.aesonnigeria.org

http://www.ajol.info/index.php/iae

Davies R. M. and O. A. Davies. 2009 Traditional and Improved Fish Processing

Technologies in Bayelsa State, Nigeria. European Journal of Scientific Research. Vol. 26 Issue 4, p539

Gorjestani, N 2000:Indigenous Knowledge for Development Opportunities and Challenges Indigenous Knowledge; paper presented at the UNCTAD Conference on Traditional Knowledge in Geneva, November 1, 2000 for Development Program The World Bank.

Kolawole, O.D. 2001. Local knowledge utilization and sustainable rural development in the 21st Century. Indigenous Knowledge and Development Monitor.

Polson, R.A. and D.S.C. Spencer, (1992): The Technology Adoption Process in Subsistence Agriculture: the case of cassava in South Western Nigeria. Agricultural System, No. 5, 1992.

Voh, J. P. (1982). A Study of Factors Associated with Adoption of Recommended Farm Practices in Nigerian Village. Agricultural Administration, 2, 17 - 27 